\title{
PERSEPSI DUKUNGAN ORGANISASI \\ DAN ORGANIZATIONAL CITIZENSHIP BEHAVIOR TERHADAP KOMITMEN ORGANISASI PADA PT. GUNUNG PUTRI PERKASA KANTOR CABANG PURWAKARTA
}

\author{
Ela Laela \\ Prodi Manajemen - STIE DR KHEZ Muttaqien Purwakarta \\ elaakbar75@gmail.com
}

\author{
Article Info \\ Article History : \\ Received 26 January 2019 \\ Accepted 14 February 2019 \\ Available Online 01 March 2019
}

\begin{abstract}
The perception of organizational support and organizational citizenship behavior has a role to increase employee organizational commitment, with perceptions of good organizational support can encourage individual employees to contribute more and give reciprocity by showing organizational citizenship behavior so as to increase employee organizational commitment. The purpose of this study was to analyze and explain the influence of perceptions of organizational support and organizational citizenship behavior on employee organizational commitment. The population in this study were employees of PT. Gunung Putri Perkasa Purwakarta Branch Office. The method of determining the sample used is disproportionate stratified random sampling, with the number of respondents as many as 60 people. The analysis technique used is multiple linear regression analysis. The results showed that the perception of organizational support and organizational citizenship behavior had a positive and significant effect on the organizational commitment of employees at PT. Gunung Putri Perkasa Purwakarta Branch Office. With this research, it is expected that companies can show attention, care, be open, give awards, and create a comfortable working atmosphere.
\end{abstract}

Keyword:

Perception of Organizational

Support, Organizational

Citizenship Behavior, Employee

Organizational Commitment

\section{PENDAHULUAN}

Sumber daya manusia yang berkompeten, mencintai organisasi dan setia terhadap organisasi menjadi aset yang sangat berharga, kecintaan dan kesetiaan karyawan terhadap perusahaan disebut sebagai komitmen organisasi. Setiap perusahaan selalu mengharapkan karyawan mempunyai komitmen yang kuat terhadap organisasi, karena karyawan yang mempunyai komitem kuat akan menampilkan kinerja terbaiknya dan produktif dalam mengemban pekerjaan. Masalah yang sering terjadi di setiap organisasi yaitu sulitnya mendapatkan terutama mempertahankan karyawan, karena pada kenyataannya tidak semua karyawan mempunyai komitmen yang kuat terhadap organisasi. Masalah komitmen 
organisasi karyawan dapat berpengaruh terhadap keberlangsungan organisasi, yang paling buruk yaitu terjadinya tingkat turnover yang tinggi, karena selain kehilangan karyawan terbaiknya, perusahaan juga membutuhkan biaya ekstra untuk mengadakan pengrekrutan kembali.

Masalah komitmen sering juga terjadi di perusahaan kontraktor, padahal untuk menyelesaikan proyek sangat membutuhkan efektifitas dan efisiensi dari berbagai pihak termasuk sumber daya manusia. Keberhasilan perusahaan kontraktor dalam menyelesaikan proyek salah satunya ditentukan oleh keberhasilan manajemen dalam menumbuhkan komitmen organisasi karyawan, komitmen organisasi karyawan ditunjukan dengan adanya loyalitas tinggi yang tercermin dari keterlibatan karyawan secara efektif dan kesetiaan karyawan dalam mencapai tujuan organisasi.

Menurut Sopiah dalam Priansa, Donni, J. (2016:232) ciri-ciri karyawan yang berkomitmen kuat dan rendah dipaparkan sebagai berikut "Karyawan yang mempunyai komitmen kuat terhadap organisasi akan menampilkan kinerja terbaiknya serta produktif dalam mengemban pekerjaan, sebaliknya jika karyawan memiliki komitmen yang rendah maka akan berdampak pada turnover, tingginya absensi, meningkatnya kelambanan kerja dan kurang intensitas untuk bertahan sebagai pegawai di organisasi tersebut, rendahnya kualitas kerja, dan kurangnya loyalitas pada organisasi."

Berdasarkan indikasi yang dipaparkan diatas mengenai ciri-ciri komitmen organisasi karyawan, diketahui bahwa komitmen organisasi karyawan PT. Gunung Putri Perkasa Kantor Cabang Purwakarta masih tergolong rendah, PT. Gunung Putri Perkasa merupakan perusahaan kontraktor yang bergerak dibidang konstruksi, rekayasa dan pengadaan umum, seperti sandblastingpainting, insulation, exterior-interior, mechanical electrical dan general contractor.

Fenomena rendahnya komitmen organisasi karyawan dapat dilihat dari data yang peneliti dapatkan dari bagian HRD dan bagian Administrasi, dimana report absensi sidik jari menunjukkan dari 144 orang karyawan pada tahun 2016 tingkat kehadiran karyawan hanya mencapai ratarata $60.13 \%$ sedangkan perusahaan mempunyai standar minimal kehadiran rata-rata $85 \%$ per tahun, Masih banyak karyawan yang datang terlambat melebihi toleransi, istirahat sebelum jam 12.00 WIB, dan pulang lebih cepat. Banyaknya karyawan yang tidak disiplin dapat mempengaruhi kerja tim, dan tentunya dapat mempengaruhi penyelesaian proyek.

Selain itu, turnover sering terjadi pada tahun 2016, dimana pada bagian office pada Bulan Februari sebanyak satu orang engineer keluar, April sebanyak dua orang supervisor keluar, Agustus tiga orang engineer, September satu orang dibagian keuangan keluar dan November satu orang estimator keluar, sedangkan dibagian lapangan mencapai 30 orang di tahun 2016. Kurangnya intensitas karyawan untuk bertahan dalam organisasi menjadi cirri-ciri karyawan tersebut kurang berkomitmen terhadap organisasi.

Persepsi dukungan organisasi harus menjadi perhatian penting bagi organisasi, pada dasarnya persepsi setiap karyawan berbeda-beda karena setiap individu mempunyai perasaan, kemampuan dan pengalaman yang berbeda. Namun karyawan yang mempunyai persepsi positif cenderung dapat menghargai dan menghormati organisasi mereka serta bersedia untuk berkontribusi dan setia terhadap organisasi karena mereka merasa dihargai keberadaannya oleh organisasi. Pemaparan tersebut sesuai dengan pendapat Dharmawan, I. P., \& Suana, I. W. (2016:6264) bahwa "Karyawan yang didukung oleh organisasi cenderung menghargai dan menghormati organisasi mereka dan karena itu bersedia untuk berkontribusi kepada tujuan organisasi." 
Dukungan organisasi dapat berupa interaksi organisasi kepada karyawan dengan memberikan perhatian terhadap kontribusi, kesejahteraan dan kondisi kerja karyawan, serta membantu jika karyawan menghadapi kesulitan ataupun masalah yang terjadi di lapangan. Fenomena yang terjadi di PT. Gunung Putri Perkasa Kantor Cabang Purwakarta, persepsi karyawan terhadap dukungan organisasi masih kurang, hal tersebut dikarenakan karena kesempatan untuk mendapatkan promosi sangat sulit didapatkan, beberapa supervisor yang kurang kooperatif, namun organisasi sangat memperhatikan keselamatan kerja karyawan dengan menyiapkan helm, sepatu, dan body harnest jika bekerja diketinggian, asuransi, dan adanya safety officer. Perusahaan juga memberikan tunjangan lokasi jika karyawan bekerja di luar kota Purwakarta, organisasi juga sudah menyediakan mes dan kontrakan bagi karyawan.

Individu yang senang menolong dan mendorong dapat meningkatkan keterikatan emosional antar karyawan, kondisi tersebut dapat menciptakan suasana kerja yang nyaman, adanya hubungan kekeluargaan, dan dapat merubah suasana yang canggung menjadi lebih santai serta penuh dengan kerja sama. Pemaparan tersebut merupakan dampak Organizational Citizenship Behavior (OCB) yang dikutip dari Titisari, Purnamie (2014:3) bahwa "Organizational Citizenship Behavior (OCB) membantu mengubah suasana organisasi yang formal menjadi sedikit santai dan penuh dengan kerja sama." Karyawan yang menampilkan perilaku OCB disebut sebagai karyawan

Rumusan masalah pada penelitian ini adalah sebagai berikut :

1. Bagaimana Pengaruh Persepsi Dukungan Organisasi Terhadap Komitmen Organisasi Karyawan PT. Gunung Putri Perkasa Kantor Cabang Purwakarta?

2. Bagaimana Pengaruh Organizational Citizenship Behavior Terhadap yang baik (Good Citizen) ketika karyawan sudah merasa nyaman dengan suasana kerjanya maka mereka mempunyai ikatan emosional dan enggan untuk meninggalkan organisasi.

Organizational

Citizenship

Behavior (Perilaku kewargaan organisasi) yang sering disebut sebagai OCB merupakan perilaku ekstra yang dimiliki individu diluar job description dan dapat meningkatkan kinerja. OCB melibatkan beberapa perilaku meliputi perilaku menolong orang lain, menjadi volunteer untuk tugas-tugas ekstra, patuh terhadap aturan dan prosedur di tempat kerja.

Fenomena yang terjadi di PT. Gunung Putri Perkasa Kantor Cabang Purwakarta, perilaku OCB diperlihatkan karyawan dengan saling membantu dalam pekerjaan terutama pekerjaan yang sifatnya urgent dan overload dengan sukarela, menghindari konflik ketika adanya miss communication, serta saling mendukung dan memberikan motivasi karena pada dasarnya penyelesaian suatu proyek sangat dibutuhkan adanya kerja sama, namun tidak semua karyawan mempunyai perilaku OCB yang tinggi, dimana ada beberapa karyawan yang terlihat berleha-leha sedangkan rekan satu timnya sedang sibuk, tidak mengikuti prosedur yang sudah ditetapkan seperti tidak mengikuti prosedur dalam pengambilan barang di gudang yang seharusnya disertai nomor proyek tapi tidak semua karyawan melakukannya sehingga hal tersebut menyulitkan bagian administrasi dan bagian control material dan administrasi.

\section{Rumusan Masalah}

Komitmen Organisasi Karyawan PT. Gunung Putri Perkasa Kantor Cabang Purwakarta?

3. Bagaimana Pengaruh Persepsi Dukungan Organisasi dan Organizational Citizenship Behavior Terhadap Komitmen Organisasi Karyawan PT. Gunung Putri Perkasa Kantor Cabang Purwakarta? 
Tujuan Penelitian

Tujuan dari penelitian ini adalah sebagai berikut :

1. Untuk mengetahui bagaimana Pengaruh Persepsi Dukungan Organisasi Terhadap Komitmen Organisasi Karyawan PT. Gunung Putri Perkasa Kantor Cabang Purwakarta.

2. Untuk mengetahui bagaimana Pengaruh Bagaimana Pengaruh Organizational Citizenship Behavior

\section{KAJIAN PUSTAKA}

\section{Persepsi Dukungan Organisasi}

Proses dimana individu mengatur dan menginterpretasikan kesan-kesan sensoris mereka guna memberikan arti bagi lingkungan mereka (Robbins \& Judge, 2014:175), sedangkan menurut Rivai dalam Mujiasih (2015) "Persepsi adalah proses kognitif yang dipahami oleh setiap orang dalam memahami sesuatu baik melalui penglihatan, pendengaran, maupun perasaan. Sejalan dengan pendapat tersebut, dapat ditarik kesimpulan bahwa persepsi merupakan proses individu dalam mengatur dan menginterpretasikan kesan dalam suatu lingkungan melalui penglihatan, pendengaran dan perasaannya."

Persepsi sangat penting dalam organisasi, karena terbentuknya perilaku individu dalam organisasi didasarkan pada persepsi mereka tentang kenyataan, bukan pada kenyataan itu sendiri, itulah sebabnya kenapa persepsi setiap individu berbedabeda. Sejumlah faktor dapat membentuk dan bahkan mengubah tentang persepsi
Terhadap Komitmen Organisasi Karyawan PT. Gunung Putri Perkasa Kantor Cabang Purwakarta.

3. Untuk mengetahui bagaimana Pengaruh Persepsi Dukungan Organisasi dan Organizational Citizenship Behavior Terhadap Komitmen Organisasi Karyawan PT. Gunung Putri Perkasa Kantor Cabang Purwakarta. individu, dimana menurut Robbins \& Judge (2014:175) "Faktor-faktor persepsi terletak pada dalam diri pembentuk persepsi, dalam diri objek atau target yang diartikan, atau dalam konteks situasi dimana persepsi tersebut dibuat."

Menurut Rhoades \& Eisenberger dalam Mujiasih (2015:44) bahwa, "Persepsi dukungan organisasi mengacu pada persepsi karyawan mengenai sejauh mana organisasi menilai kontribusi mereka dan peduli terhadap kesejahteraan mereka." Eisenberger melanjutkan "Dukungan organisasi juga dianggap sebagai sebuah keyakinan global yang dibentuk oleh tiap karyawan mengenai penilaian mereka terhadap kebijakan dan prosedur organisasi yang dibentuk berdasarkan pada pengalaman mereka terhadap kebijakan dan prosedur organisasi, penerimaan sumber daya, interaksi dengan agen organisasinya (misalnya supervisor) dan persepsi mereka mengenai kepedulian organisasi terhadap kesejahteraan mereka (misalnya gaji)."

\section{Perilaku Kewargaan Organisasi (Organizational Citizenship Behavior)}

Perilaku kewargaan organisasi yang lebih sering disebut sebagai Organizational Citizenship Behavior (OCB) merupakan perilaku individu yang bebas diluar kewajiban kerja formal yang terdapat dalam job description, tidak secara langsung berkaitan dengan sistem reward dalam perusahaan, namun keberadaanya mampu meningkatkan efisiensi dan efektifitas organisasi, OCB menjadi perilaku yang penting dalam organisasi karena selain dapat meningkatkan efektifitas organisasi, OCB juga dapat menciptakan suasana lingkungan pekerjaan yang menyenangkan, dimana 
kondisi kerja yang formal menjadi sedikit lebih santai dan penuh dengan kerja sama. Pemaparan diatas sesuai dengan pendapat dari Organ, et al. dalam Dora, dkk. (2017:38) menggambarkan "OCB sebagai perilaku individual yang bersifat bebas (discretionary), yang tidak secara langsung dan eksplisit dapat penghargaan dari sistem imbalan formal, dan yang secara keseluruhan (agregat) meningkatkan efisiensi dan efektifitas fungsi-fungsi organisasi." Sedangkan Robbins dan Judge (2014:40) berpendapat bahwa "Organizational citizenship behavior adalah perilaku pilihan yang tidak menjadi bagian dari kewajiban kerja formal seorang karyawan, namun mendukung berfungsinya organisasi tersebut secara efektif."

Menurut Aldag \& Resckhe dalam Titisari (2014:5) "Perilaku-perilaku OCB menggambarkan nilai tambah karyawan yang merupakan salah satu bentuk perilaku prososial, yaitu perilaku sosial yang positif, konstruktif, dan bermakna membantu". Menurut Organ dalam Titisari (2014:5) "Organizational Citizenship

\section{Komitmen Organisasi}

Allen dan Meyer dalam Wiwiek dan Sondakh (2015:77) bahwa "Komitmen organisasi sebagai kemauan atau keinginan yang kuat dari anggota organisasi untuk tetap berada, bekerja, dan memiliki keterikatan dalam organisasi. Menurut Luthans dalam Priansa (2016) menyatakan bahwa "Sebagai suatu sikap, maka komitmen organisasi sering didefinisikan sebagai: a) Keinginan yang kuat untuk tetap menjadi bagian dari anggota organisasi tertentu; b) keinginan untuk berusaha keras sesuai keinginan organisasi; c) keyakinan tertentu, penerimaan nilai dan tujuan organisasi."
Behavior (OCB) dapat meningkatkan kemampuan organisasi untuk menarik dan mempertahankan karyawan terbaik, dimana perilaku menolong dapat meningkatkan moril dan keeratan serta perasaan saling memiliki diantara anggota kelompok sehingga akan meningkatkan kinerja organisasi dan membantu organisasi menarik serta mempertahankan karyawan yang baik, memberikan contoh kepada karyawan dengan perilaku OCB (misal tidak mengeluh karena permasalahan-permasalahan kecil) dapat menumbuhkan loyalitas dan komitmen pada organisasi."

Menurut Titisari (2014:9) "Seperti halnya sebagian besar perilaku yang lain, OCB ditentukan oleh banyak hal, artinya tidak ada penyebab tunggal dalam OCB." Menurut Siders et al. dalam Titisari (2014:13) bahwa, "Meningkatnya perilaku OCB dipengaruhi oleh dua faktor utama, yaitu faktor yang berasal dari dalam diri karyawan seperti moral dan sikap positif, sedangkan faktor yang berasal dari luar seperti sistem manajemen, kepemimpinan, budaya, dll.

Komitmen yang tinggi mencerminkan keberpihakan individu yang tinggi terhadap organisasi, sedangkan seseorang yang kurang berkomitmen akan terlihat menarik diri dari organisasi baik melalui ketidakhadiran ataupun turnover. Masalahmasalah tersebut sering timbul dalam suatu organisasi dan dapat mempengaruhi kinerja organisasi secara keseluruhan, terutama turnover. Tingginya turnover dapat mempengaruhi stabilitas organisasi dan membuat organisasi harus mengeluarkan biaya lebih untuk perekrutan ulang. 


\section{Hipotesis}

1. $\mathrm{H}_{1}$ : Diduga Persepsi dukungan organisasi berpengaruh positif dan signifikan terhadap komitmen organisasi karyawan PT. Gunung Putri Perkasa Kantor Cabang Purwakarta.

2. $\mathrm{H}_{2}$ : Diduga Perilaku kewargaan organisasi (organizational citizenship behavior) bepengaruh positif dan signifikan terhadap komitmen

\section{METODOLOGI PENELITIAN}

Metode yang digunakan dalam penelitian ini adalah metode deskriptif kuantitatif, bahwa kegunaan metode ini untuk mengetahui suatu gejala dalam penelitian serta menjelaskan pengaruh dan hubungan dari suatu fenomena melalui uji hipotesis. Jenis metode deskriptif kuantitatif yang digunakan dalam metode survey. Metode survey digunakan untuk mendapatkan data dari tempat tertentu dengan cara, peneliti melakukan pengumpulan data dengan membagikan kuesioner.

\section{Metode Sampel}

Ada dua golongan dalam pengelompokkan data yang dapat menunjang hasil penelitian yang akan dilakukan, yaitu : Populasi dari penelitian ini adalah karyawan dibagian Team Project yang berjumlah 144 orang. Sampel adalah bagian dari jumlah dan karakteristik yang dimiliki oleh populasi pada sebuah penelitian. Sampel pada penelitian ini menggunakan teknik Probability Sampling, dimana teknik pengambilan sampel ini memberikan

\section{HASIL DAN PEMBAHASAN}

\section{Uji Hipotesis}

Uji t digunakan untuk menguji signifikansi konstanta dari setiap variabel independen, apakah variabel Persepsi Dukungan Organisasi $\left(\mathrm{X}_{1}\right)$ dan Perilaku Kewargaan Organisasi (Organizational Citizenship Behavior) $\left(\mathrm{X}_{2}\right)$ berpengaruh secara parsial (terpisah) terhadap variabel dependennya yaitu Komitmen Organisasi Karyawan (Y). Nilai $t_{\text {hitung }}$ dapat dilihat dari nilai regresi hasil output SPSS versi 20 sedangkan nilai organisasi karyawan PT. Gunung Putri Perkasa Kantor Cabang Purwakarta.

3. $\mathrm{H}_{3}$ : Diduga Persepsi dukungan organisasidan perilaku kewargaan organisasi (organizational citizenship behavior) berpengaruh positif dan signifikan terhadap komitmen organisasi karyawan PT. Gunung Putri Perkasa Kantor Cabang Purwakarta.

peluang yang sama bagi setiap anggota populasi untuk dipilih menjadi sampel. Metode dalam penelitian ini menggunakan Disproportionate Stratified Random Sampling, teknik ini digunakan untuk menentukan jumlah sampel bila populasi berstrata tapi kurang proposional. Metode ini diambil karena karakteristik yang dimiliki oleh populasi bersifat heterogen. Untuk menentukan jumlah sampel yang akan diambil ialah dengan menggunakan rumus Slovin Dari perhitungan diatas, maka sampel yang akan diambil untuk diteliti di PT. Gunung Putri Perkasa Kantor Cabang Purwakarta sebanyak 60 orang yang akan mewakili populasi yang berjumlah 144 orang karyawan. Populasi sendiri terbagi menjadi dua bagian, yang masing-masing berjumlah :

1) Team project $=126$ orang

2) Team H. O. = 18 orang

Dari jumlah diatas, maka seluruh populasi di team H. O. akan digunakan sebagai sampel, dan untuk team project berjumlah 42 orang.

$\mathrm{t}_{\text {tabel }}$ dapat dicari (a) $=5 \%: 2=2.5 \%$ (uji dua sisi) dengan derajat kebebasan (df) n$\mathrm{k}-1$ atau $60-2-1=57$. Dengan pengujian dua sisi (signifikansi $=0.025$ ) hasil perolehan $\mathrm{t}_{\text {tabel }}$ sebesar 2.002. Hasil menunjukkan bahwa nilai $t_{\text {hitung }}$ Persepsi Dukungan Organisasi $\left(X_{1}\right) \leq$ nilai $t_{\text {tabel }}(0.622 \leq 2.002)$ dan nilai signifikansi $(0.536 \geq 0.05)$, sedangkan nilai $t_{\text {hitung }}$ Perilaku Kewargaan Organisasi (Organizational Citizenship 
Behavior $)\left(\mathrm{X}_{2}\right) \geq$ nilai $\mathrm{t}_{\text {tabel }}(6.826 \geq 2.002$ dan nilai signifikansi $(0.00 \leq 0.05)$, berarti

\section{Pengaruh Persepsi Dukungan Organisasi terhadap Y Komitmen Organisasi}

Kriteria yang digunakan untuk menguji hipotesis pengaruh Persepsi Dukungan Organisasi $\left(\mathrm{X}_{1}\right)$ terhadap Komitmen Organisasi Karyawan (Y) adalah sebagai berikut:

a) $\mathrm{H}_{0}: \beta_{1} \mathrm{X}_{1}=0$, Persepsi Dukungan Organisasi tidak memiliki pengaruh yang positif terhadap komitmen organisasi karyawan.

b) $\mathrm{H}_{\mathrm{a}}: \beta_{1} \mathrm{X}_{1} \neq 0$, Persepsi Dukungan Organisasi memiliki pengaruh yang positif terhadap komitmen organisasi karyawan.

Berdasarkan hasil output SPSS 20 dan kriteria hipotesis diatas, diketahui bahwa $\mathrm{H}_{\mathrm{a}}: 0.019 \neq 0$, hal tersebut menunjukkan bahwa variabel Persepsi Dukungan Organisasi $\left(\mathrm{X}_{1}\right)$ berpengaruh positif terhadap Komitmen Organisasi Karyawan (Y).

Setelah diketahui pengaruhnya, maka selanjutnya dilakukan pengujian berdasarkan tingkat signifikansi. Kriteria pengujian dengan tingkat signifikansi (a) = 0,05 ditentukan sebagai berikut: Berdasarkan hasil output SPSS 20 dan kriteria pengujian diatas, diketahui bahwa $\mathrm{t}_{\text {hitung }} \leq \mathrm{t}_{\text {tabel }}(0.536 \geq 0.05)$ maka Ho diterima Ha ditolak, yang artinya Persepsi Dukungan Organisasi $\left(\mathrm{X}_{1}\right)$ berpengaruh tidak signifikan terhadap Komitmen Organisasi Karyawan (Y).

\section{Pengaruh OCB Organizational Citizenship Behavior) terhadap Komitmen Organisasi}

Kriteria yang digunakan untuk menguji hipotesis Perilaku Kewargaan Organisasi (Organizational Citizenship Behavior) $\left(\mathrm{X}_{2}\right)$ terhadap Komitmen Organisasi Karyawan (Y) adalah sebagai berikut: Berdasarkan hasil output SPSS 20 dan kriteria hipotesis diatas, diketahui bahwa $\mathrm{H}_{\mathrm{a}}: 3.364 \neq 0$, hal tersebut menunjukkan bahwa variabel Perilaku Kewargaan Organisasi (Organizational Citizenship Behavior) $\left(\mathrm{X}_{2}\right)$ berpengaruh positif terhadap Komitmen Organisasi Karyawan (Y). Setelah diketahui pengaruhnya, maka selanjutnya dilakukan pengujian berdasarkan tingkat signifikansi. Kriteria pengujian dengan tingkat signifikansi (a) = 0,05 ditentukan sebagai berikut: Berdasarkan hasil output SPSS 20 dan kriteria pengujian diatas, diketahui bahwa $t_{\text {hitung }} \geq t_{\text {tabel }}(0.00 \leq 0.05)$ maka Ho ditolak Ha diterima artinya Perilaku Kewargaan Organisasi (Organizational Citizenship Behavior) berpengaruh signifikan terhadap Komitmen Organisasi Karyawan (Y).

\section{Uji simultan (F-tes)}

Uji $F$ digunakan untuk mengetahui pengaruh variabel independen yaitu Persepsi Dukungan Organisasi $\left(\mathrm{X}_{1}\right)$ dan Perilaku Kewargaan Organisasi (Organizational Citizenship Behavior) $\left(\mathrm{X}_{2}\right)$ secara simultan terhadap variabel dependen yaitu Komitmen Organisasi Karyawan (Y).

Nilai $F_{\text {hitung }}$ dapat dilihat dari nilai regresi hasil output SPSS versi 20 sedangkan nilai $\mathrm{F}_{\text {tabel }}$ dapat dicari $\mathrm{a}=5 \%: 2=2.5 \%$ (uji dua sisi) dengan derajat kebebasan df 1 (jumlah variabel -1 ) atau 3-1=2 dan df 2 (n-k-1) atau 60-2-1=57. maka diperolehan hasil $\mathrm{F}_{\text {tabel }}$ sebesar 3.159. Berdasarkan hasil perhitungan menunjukkan bahwa nilai $F_{\text {hitung }}$ Persepsi Dukungan Organisasi $\left(\mathrm{X}_{1}\right)$ dan Perilaku Kewargaan Organisasi (Organizational Citizenship Behavior) $\left(\mathrm{X}_{2}\right)$ lebih besar dari $\mathrm{F}_{\text {tabel }}(35.119 \geq 3.159)$ dan nilai signifikansi $(0.00 \leq 0.05)$. Kriteria pengujian dengan tingkat kepercayaan sebesar $95 \%$ atau taraf signifikansi sebesar 5\% adalah sebagai berikut:Berdasarkan hasil output SPSS 20 dan kriteria pengujian diatasdiketahui bahwa $\mathrm{F}_{\text {hitung }} \geq \mathrm{F}_{\text {tabel }}$ maka $\mathrm{H}_{0}$ ditolak dan Ha diterima, artinya terdapat pengaruh yang positif dan signifikan antara Persepsi Dukungan Organisasi $\left(\mathrm{X}_{1}\right)$ dan Perilaku Kewargaan Organisasi (Organizational Citizenship Behavior) $\left(\mathrm{X}_{2}\right)$ secara simultan 


\section{Pembahasan Penelitian}

Berdasarkan hasil pengujian secara statistik dapat dilihat dengan jelas bahwa:

\section{Pengaruh Persepsi Dukungan Organisasi Terhadap Komitmen Organisasi Karyawan}

Hasil deskriptif menunjukkan bahwa persepsi dukungan organisasi mempunyai kriteria yang baik dengan hasil sebesar 3.54, sedangkan komitmen organisasi karyawan mempunyai hasil sebesar 3.81 dengan kriteria baik. Hasil pengujian hipotesis $\left(\mathrm{H}_{1}\right)$ secara statistik membuktikan bahwa persepsi dukungan organisasi mempunyai pengaruh yang positif tapi tidak signifikan terhadap komitmen organisasi karyawan pada PT. Gunung Putri Perkasa Kantor Cabang Purwakarta, hal tersebut ditunjukkan dengan uji parisal dengan hasil $\mathrm{H}_{\mathrm{a}}: 0.019$ $\neq 0$, artinya variabel Persepsi Dukungan Organisasi $\left(\mathrm{X}_{1}\right)$ berpengaruh positif terhadap Komitmen Organisasi Karyawan (Y) sedangkan $t_{\text {hitung }} \leq t_{\text {tabel }}(0.536 \geq 0.05)$ maka Ho diterima Ha ditolak, yang artinya Persepsi Dukungan Organisasi $\left(\mathrm{X}_{1}\right)$ berpengaruh tidak signifikan terhadap Komitmen Organisasi Karyawan (Y). Penelitian terdahulu yang dilakukan oleh Ni Putu Lady A., dkk. (2017) dengan judul Pengaruh Perceived Organizational Support terhadap Turnover dengan Komitmen Organisasi sebagai variabel pemediasi dengan hasil yang menunjukkan bahwa perceived organizational support mempunyai pengaruh negatif terhadap turnover, perceived organizational support mempunyai pengaruh positif dan signifikan terhadap komitmen organisasi, dan komitmen organisasi terindikasi memediasi pengaruh organizational support terhadap turnover. Perbedaannya dengan penelitian ini yaitu dari hasil, dimana persepsi dukungan organisasi berpengaruh tidak signifikan, hal tersebut bisa terjadi karena responden yang dipilih berbeda dan tempat penelitiannya pun berbeda. Jika perusahaan ingin meningkatkan komitmen organisasi karyawan maka Persepsi Dukungan Organisasi $\left(\mathrm{X}_{1}\right)$ dapat ditingkatkan namun tidak menjadi prioritas utama karena tidak akan berdampak besar bagi peningkatan komitmen organisasi karyawan.

\section{Pengaruh Perilaku Kewargaan Organisasi (Organizational Citizenship Behavior) Terhadap Komitmen Organisasi Karyawan}

Hasil deskriptif menunjukkan bahwa perilaku kewargaan organisasi (organizational citizenship behavior) mempunyai kriteria yang baik dengan hasil sebesar 3.85 sedangkan hasil pengujian hipotesis $\left(\mathrm{H}_{2}\right)$ secara statistik membuktikan bahwa perilaku kewargaan organisasi (organizational citizenship behavior) mempunyai pengaruh yang positif dan signifikan terhadap komitmen organisasi karyawan pada PT. Gunung Putri Perkasa Kantor Cabang Purwakarta, hal tersebut ditunjukkan dengan uji parisal dengan hasil $\mathrm{H}_{\mathrm{a}}: 3.364 \neq 0$, hal tersebut menunjukkan bahwa variabel Perilaku Kewargaan Organisasi (Organizational Citizenship Behavior) $\left(\mathrm{X}_{2}\right)$ berpengaruh positif terhadap Komitmen Organisasi Karyawan $(\mathrm{Y})$ sedangkan $\mathrm{t}_{\text {hitung }} \geq \mathrm{t}_{\text {tabel }}(0.00$ $\leq 0.05)$ maka Ho ditolak Ha diterima yang artinya Perilaku Kewargaan Organisasi (Organizational Citizenship Behavior) $\left(\mathrm{X}_{2}\right)$ berpengaruh signifikan terhadap Komitmen Organisasi Karyawan (Y).

Penelitian terdahulu dilakukan oleh Kadek mahendra \& I G A Dewi (2017) dengan judul Pengaruh Kepemimpinan Transformasional dan OCB terhadap Kinerja Karyawan dengan mediasi Komitmen Organisasi hasil penelitiannya menunjukkan bahwa kepemimpinan transformasional berpengaruh positif dan signifikan terhadap komitmen organisasi, kepemimpinan transformasional berpengaruh positif dan signifikan 
terhadap kinerja karyawan, OCB berpengaruh positif dan signifikan terhadap komitmen organisasi, OCB berpengaruh positif dan signifikan terhadap kinerja karyawan, serta komitmen organisasi berpengaruh positif dan signifikan terhadap kinerja karyawan. Hasil penelitian tersebut sama dengan penelitian ini yaitu perilaku kewargaabn organisasi mempunyai pengaruh yang positif dan signifikan terhadap konitmen organisasi karyawan.

Jika perusahaan ingin meningkatkan komitmen organisasi karyawan maka Perilaku Kewargaan Organisasi (Organizational Citizenship Behavior) $\left(\mathrm{X}_{2}\right)$ dapat ditingkatkan dan dijadikan sebagai prioritas utama karena mempunyai nilai signifikansi yang besar, artinya dapat berdampak besar terhadap peningkatan komitmen organisai karyawan.

\section{Pengaruh Persepsi Dukungan Organisasi dan Perilaku Kewargaan Organisasi (Organizational Citizenship Behavior) Terhadap Komitmen Organisasi Karyawan}

Hasil pengujian hipotesis $\left(\mathrm{H}_{3}\right)$ secara statistik membuktikan bahwa $F_{\text {hitung }} \geq \mathrm{F}_{\text {tabel }}$ maka $\mathrm{H}_{0}$ ditolak dan $\mathrm{Ha}$ diterima, artinya terdapat pengaruh yang positif dan signifikan antara Persepsi Dukungan Organisasi $\left(\mathrm{X}_{1}\right)$ dan Perilaku Kewargaan Organisasi (Organizational Citizenship Behavior) $\left(\mathrm{X}_{2}\right)$ secara simultan terhadap Komitmen Organisasi Karyawan (Y) pada PT. Gunung Putri Perkasa Kantor Cabang Purwakarta.

Persepsi dukungan organisasi dan perilaku kewargaan organisasi berpengaruh positif dan simultan didukung oleh penelitian yang dilakukan oleh I Putu Dharmawan dan I Wayan Suana (2016:6264) bahwa "Karyawan yang didukung oleh organisasi cenderung menghargai dan menghormati organisasi mereka dan karena itu bersedia untuk berkontribusi kepada tujuan organisasi."dan oleh Organ dalam Purnamie Titisari (2014:5) "Organizational Citizenship Behavior
(OCB) dapat meningkatkan kemampuan organisasi untuk menarik dan mempertahankan karyawan terbaik, dimana perilaku menolong dapat meningkatkan moril dan keeratan serta perasaan saling memiliki diantara anggota kelompok sehingga akan meningkatkan kinerja organisasi dan membantu organisasi menarik serta mempertahankan karyawan yang baik, memberikan contoh kepada karyawan dengan perilaku OCB (misal tidak mengeluh karena permasalahan-permasalahan kecil) dapat menumbuhkan loyalitas dan komitmen pada organisasi."

\section{KESIMPULAN}

Berdasarkan judul penelitian, rumusan masalahan, tujuan penelitian, rumusan hipotesis, dan pembahasan hasil penelitian, maka dapat hasil dari penelitian ini dapat disimpulkan sebagai berikut:

Pertama. Persepsi Dukungan Organisasi berpengaruh positif tapi tidak signifikan terhadap Komitmen Organisasi Karyawan pada PT. Gunung Putri Perkasa Kantor Cabang Purwakarta, artinya semakin baik persepsi yang dirasakan karyawan mengenai dukungan organisasi maka komitmen organisasi karyawan juga semakin meningkat, namun karena tidak signifikan maka peningkatan persepsi dukungan organisasi tidak akan berdampak banyak terhadap peningkatan komitmen.

Kedua, Perilaku Kewargaan Organisasi (Organizational Citizenship Behavior) berpengaruh positif dan signifikan terhadap Komitmen Organisasi Karyawan pada PT. Gunung Putri Perkasa Kantor Cabang Purwakarta, artinya semakin baik perilaku kewargaan organisasi karyawan maka komitmen organisasi karyawan juga meningkat, karena mempunyai hasil yang signifikan maka perilaku kewargaan organisasi dapat dijadikan sebagai prioritas utama untuk meningkatkan komitmen organisasi karyawan.

Ketiga, Secara simultan terdapat pengaruh yang positif dan signifikan antara Persepsi Dukungan Organisasi dan Perilaku 
Kewargaan Organisasi (Organizational Citizenship Behavior) terhadap Komitmen Organisasi Karyawan pada PT. Gunung Putri Perkasa Kantor Cabang Purwakarta. Hasil uji simultan menunjukkan $F_{\text {hitung }} \geq$ $\mathrm{F}_{\text {tabel }}$ maka $\mathrm{H}_{0}$ ditolak dan $\mathrm{Ha}$ diterima, artinya semakin baik persepsi dukungan organisasi yang karyawan rasakan dari organisasi maka semakin tinggi pula perilaku kewargaan organisasi karyawan terhadap komitmen organisasi karyawan, artinya ketika nilai kedua variabel meningkat maka semakin meningkat pula komitmen organisasi karyawan pada PT. Gunung Putri Perkasa Kantor Cabang Purwakarta.

\section{SARAN}

Berdasarkan pembahasan dan kesimpulan dalam penelitian ini, adapun saran untuk perbaikan yang dapat disampaikan kepada PT. Gunung Putri Perkasa Kantor Cabang Purwakarta adalah sebagai berikut:

Pertama, Berdasarkan hasil analisis yang dilakukan, dinyatakan persepsi dukungan organiasai berpengaruh positif tapi tidak signifikan terhadap komitmen organisasi karyawan, artinya persepsi dukungan organisasi dapat dijadikan sebagai solusi untuk meningkatkan komitmen organisasi karyawan, namun tidak menjadi prioritas yang utama. Berdasarkan tingkat penilaian yang dilakukan kepada responden terdapat jawaban yang beragam yaitu cukup dan baik. Nilai terkecil ada pada dimensi dukungan atasan (supervisor support) pada indikator atasan tidak mengabaikan keluhan karyawan dan atasan menunjukan kepedulian terhadap kesejahteraan karyawan, oleh karena itu organisasi harus melakukan pengawasan kepada setiap atasan dan memberikan pengarahan, untuk menunjukkan perhatian dan kepedulian kepada karyawan, karena pada dasarnya perhatian dan kepedulian dari atasan dapat menjadi suatu motivasi dan karyawan pun merasa keberadaanya diakui dalam organisasi, ketika dukungan dari organisasi diterima dengan baik oleh karyawan maka hal tersebut dapat meningkatkan komitmen organisasi karyawan.

Kedua, Berdasarkan hasil analisis yang dilakukan, dinyatakan perilaku kewargaan organisasi (organizational citizenship behavior) berpengaruh positif dan signifikan terhadap komitmen organisasi karyawan, artinya perilaku kewargaan organisasi (organizational citizenship behavior) dapat dijadikan prioritas utama sebagai solusi untuk meningkatkan komitmen organisasi karyawan. Berdasarkan tingkat penilaian yang dilakukan kepada responden terdapat jawaban dengan kriteria baik. Nilai terkecil ada pada dimensi kebijakan sipil (civic virtue) dengan indikator menyumbangkan gagasan baru, oleh karena itu organisasi bisa mengadakan rapat mingguan atau bulanan sebagai wadah untuk menerima setiap masukan dari karyawan, dan memberikan penghargaan ketika ide baru tersebut berhasil, sehingga setiap karyawan akan merasa dihargai pendapatnya dan akan menjadikan sebuah motivasi bagi karyawan lain, dan mendorong peningkatan komitmen organisasi karyawan

Ketiga, Secara simultan terdapat pengaruh antara persepsi dukungan organisasi dan perilaku kewargaan organisasi (organizational citizenship behavior) pada PT. Gunung Putri Perkasa Kantor Cabang Purwakarta, artinya ketika persepsi dukungan organisasi dan perilaku kewargaan organisasi (organizational citizenship behavior) ditingkatkan, maka komitmen organisasi karyawan juga akan meningkat. 
DAFTAR PUSTAKA

Agustini, Ni Putu L., dkk. 2017. Pengaruh Perceived Organizational Support Terhadap Turnover Intention Dengan Komitmen Organisasional Sebagai Variabel Pemediasi. EJurnal Ekonomi dan Bisnis Universitas Udayana 6.1 251-276.

Dharmawan, I. P., \& Suana, I. W. 2016. Pengaruh Perceived Organizational Support dan Komitmen Organisasi Terhadap Turnover Intention Karyawan. Jurnal Manajemen, 6260-6287.

Dora, dkk,. 2017. Pengaruh Kepemimpinan Transformasional Terhadap Organizational Citizenship Behavior (OCB) dan Komitmen Organisasi Melalui Kepuasan Kerja Karyawan PT. Bank Panin, Tbk Banjarbaru. Jurnal Bisnis dan Pembangunan. Vol 6, No. 1.

Hariandja, Marihot Tua Efendi. 2002. Manajemen Sumber Daya Manusia. Jakarta: Grasindo.

Hasibuan, Malayu, S. P. 2007. Manajemen Sumber Daya Manusia. Jakarta: Bumi Aksara.

Kusendi, Rahmanto. 2011. Pengaruh Persepsi Terhadap Dukungan Organisasi

Dan Kecerdasan Emosi Terhadap Konflik Pekerjaan - Keluarga. HUMANIORA Vol.2 No.1.

Mujiasih, Endah. 2015. Hubungan Antara Persepsi Dukungan Organisasi (Perceived Organizational Support) Dengan Keterikatan Karyawan (Employee Engagement). Jurnal Psikologi Undip, 40-51.

Priansa, Donni, J. 2014. Perencanaan dan Pengembangan SDM. Bandung: ALFABETA.
Putra, Kadek Mahendra, \& Adnyani, I G A Dewi. 2016. Pengaruh Kepemimpinan Transformasional dan OCB Terhadap Kinerja Karyawan dengan Mediasi Komitmen Organisasi Pada PT. BPR Jaya Kerti. E-Jurnal Manajemen Unud, Vol. 5, No. 5, 2016: 2885 - 2917.

Robbins, Stephen P. and Judge Thimoty A. 2008. Organizational Behavior, $12^{\text {th }}$ ed. Trans. Diana Angelica, Rio Cahyani dan Abdul Rosyid. Jakarta: Salemba Empat.

Sukrajap, Muhamad A. 2016. Pengaruh Kepemimpinan Transformasional Terhadap Kepuasan Kerja dan Komitmen Organisasional Dengan Dimediasi Oleh Pemberdayaan Psikologis. Jurnal Psikologi, 25574694.

Titisari, Purnamie. 2014. Peranan Organizational Citizenship Behavior (OCB) Dalam Meningkatkan Kinerja Karyawan. Jakarta: Mitra Wacana Media.

Vannecia, dkk. 2013. Pengaruh Kepuasan Kerja dan Loyalitas Kerja Terhadap Organizational Citizenship Behavior Pada Karyawan PT. Surya Timur Sakti Jatim. AGORA.

Waileruny, Hulawa, T. 2014. Perceived Organizational Support, Job Satisfaction dan Organizational Citizrnship Behavior Pada PT. Bank Maluku Cabang Utama Kota Ambon. AGORA. Vol. 2, No. 2.

Wiwiek, \& Sondakh, O. 2015. Pengaruh Keadilan Organisasional Pada Motivasi Karyawan dan Komitmen Organisasional. Siasat Bisnis, 6977. 